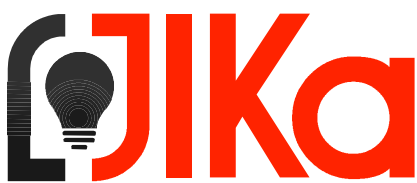

JURNAL INOVASI \& KREATIVITAS
JURNAL INOVASI DAN KREATIVITAS (JIKa)

Volume 1 Nomor 1 2021; p-ISSN 2776-1843

Doi: dx.doi.org/10.30656/JIKa.v1i1.3282

https://e-jurnal.Ippmunsera.org/index.php/JIKa

SK No. 0005.27761843/K.4/SK.ISSN/2021

\title{
PENGARUH TERPAAN TAYANGAN "SUARA HATI ISTRI" \\ DI INDOSIAR TERHADAP TINGKAT KECEMASAN PENONTON (Studi pada Kalangan Ibu Rumah Tangga di Kota Serang)
}

\author{
THE INFLUENCE OF INDOSIAR'S "WIFE'S VOICE" \\ ON THE LEVEL OF VISIBLE ANXIETY \\ (STUDY ON HOUSEHOLD WOMEN IN SERANG CITY)
}

\section{Nita Maediana Rusmawatia, Siska Mardiana, Indrianti Azhar Firdausi}

Program Studi Ilmu Komunikasi, Fakultas Ilmu Sosial, dan Hukum, Universitas Serang Raya nmaediana49@gmail.com, mardiana.siska@yahoo.com, indriantiazhar@gmail.com

\section{Abstract}

Problems: The show of the Conscience of the Wife on Indosiar is a drama story about domestic problems from the perspective of a woman who is inspired by the outpouring of the hearts of abused wives. This broadcast shows a scene of a wife who is hurt because of her husband.

Purpose: To find out the effect of watching and how much influence the Suara Hati wife broadcasts in Indosiar have on the anxiety level of female viewers among homemakers.

Methodology: This research method uses a quantitative approach. The method used was a survey by distributing questionnaires to 398 homemakers in Serang City.

Results/Findings: The results of the t-test with the results of the determination coefficient of $52.7 \%$, which indicates that the anxiety of homemakers in Serang City is influenced by exposure to the Voice of the Wife's broadcast in Indosiar, while the other $47.3 \%$ is explained by other variables not studied. In this research, this study concludes that the Suara Hati Wife program in Indosiar has a positive effect on the anxiety level of female viewers among homemakers in Serang City.

Paper Type: field research

Keywords: Audience Anxiety; Cultivation; Exposure Impressions 
Masalah: Tayangan Suara Hati Istri di Indosiar merupakan kisah drama tentang problematika rumah tangga dari sudut pandang seorang wanita yang terinspirasi dari curahan hati para istri yang terzalimi. Tayangan ini mempertontonkan adegan seorang istri yang tersakiti karena ulah suaminya sendiri.

Tujuan: Mengetahui pengaruh menonton dan seberapa besar pengaruh tayangan Suara Hati Istri di Indosiar terhadap tingkat kecemasan penonton wanita di kalangan Ibu Rumah Tangga.

Metodologi: Metode penelitian ini menggunakan pendekatan kuantitatif. Metode yang digunakan adalah survei dengan menyebar kuesioner kepada 398 responden Ibu Rumah Tangga di Kota Serang.

Temuan/Hasil Penelitian: Hasil uji t dengan hasil koefisien determinasi sebesar 52,7\% yang menandakan bahwa kecemasan Ibu Rumah Tangga di Kota Serang dipengaruhi oleh terpaan tayangan Suara Hati Istri di Indosiar, sementara 47,3\% lainnya diterangkan oleh variabel lain yang tidak diteliti dalam penelitian ini. Penelitian ini menyimpulkan bahwa tayangan Suara Hati Istri di Indosiar memiliki pengaruh positif terhadap tingkat kecemasan penonton wanita pada kalangan Ibu Rumah Tangga di Kota Serang..

Jenis penelitian: Riset lapangan

Kata kunci: Kecemasan Penonton; Kultivasi; Terpaan Tayangan

\section{A. PENDAHULUAN}

$\begin{array}{rcrr}\text { Media } & \text { massa } & \text { merupakan } & \text { saluran } \\ \text { atau alat } & \text { yang digunakan } & \text { dalam } \\ \text { komunikasi } & \text { massa. Dilihat } & \text { dari }\end{array}$
perkembangannya, media massa dapat dibagi menjadi dua kategori yaitu media massa cetak dan media massa elektronik. Media cetak diantaranya adalah surat kabar dan majalah. Sementara media elektronik diantaranya adalah televisi, radio siaran, film, lalu saat ini kembali berkembang ke dalam media baru yaitu internet.

Salah satu keunggulan televisi yaitu sebagai media audiovisual yang mudah diakses, televisi mengalami perkembangan yang cukup pesat dari waktu ke waktu. Belakangan televisi bukan lagi menjadi sebuah barang mahal, sebab hampir semua orang memiliki televisi di rumahnya paling tidak satu buah sebagai sarana hiburan dan informasi yang paling mudah diakses.

Pemirsa televisi dihadapkan kepada banyak alternatif tontonan dari berbagai acara televisi yang berbeda. Sebagaimana fungsi utamanya sebagai sarana hiburan, program hiburan di televisi pun dapat dibagi menjadi dua kategori utama yaitu kategori program non-drama dan program drama televisi (Morissan, 2011:207). Tayangan drama di Indonesia sendiri sering mendapat sambutan hangat di hati pemirsanya. Drama atau sinetron yang tampil di layar kaca stasiun televisi Indonesia hampir tidak pernah sepi penonton. Bahkan sinetron yang memiliki rating tinggi seringkali mencapai ribuan episode dengan alur cerita yang tidak jelas jika diamati. Sinetron yang alurnya tidak jelas dan memiliki episode yang panjang disebabkan karena sistem kejar tayang yang dilakukan oleh para tim produksi sinetron (Kuswandi, 2008:112). Drama sinetron tersebut selalu berebut tempat di posisi pertama di tangga rating meski banyak adegan tidak masuk akal dan plot cerita yang lemah.

Salah satu stasiun televisi komersial di Indonesia yaitu Indosiar menayangkan program drama FTV Keluarga dengan judul Suara Hati Istri yang tayang sejak Oktober 
2019. Dikutip dari laman resmi Indosiar, Suara Hati Istri merupakan kisah drama tentang problematika rumah tangga dari sudut pandang seorang wanita yang terinspirasi dari curahan hati para istri yang terzalimi. Suara Hati Istri menghadirkan kisah menyedihkan yang dialami oleh seorang istri, kisah-kisah tersebut diantaranya menggambarkan tentang sikap suami yang ringan tangan, suami yang ingin poligami, suami yang selingkuh, dan bermacam-macam kisah para istri yang tersiksa oleh suaminya sendiri. Berdasarkan observasi pra penelitian, drama Suara Hati Istri tayang di Indosiar setiap hari sebanyak dua episode pada pukul 16.30 WIB dan 18.30 WIB. Durasi tayang Suara Hati Istri tiap satu episode sekitar 120 menit sudah termasuk iklan. Maka dalam sehari Suara Hati Istri tayang selama 240 menit atau selama 4 jam termasuk iklan.

Penelitian ini membatasi tayangan Suara Hati Istri pada episode tentang kesalahan yang dilakukan oleh suami. Kisah-kisah yang diangkat dalam serial drama Suara Hati Istri diantaranya berjudul Aku tak ingin mengalah dan kalah dari istri simpanan suamiku, Aku selalu setia pada suamiku meskipun disakitinya, Dulu sahabatku sekarang jadi maduku, Suamiku menikah kalau dirumah kalau diluar mengaku bujangan.

Dilihat dari judul-judul yang tayang tiap serinya, drama Suara Hati Istri selalu mempertontonkan adegan seorang istri yang tersiksa batin karena suaminya. Menurut Gerbner makin sering seseorang menonton televisi, makin mirip persepsinya tentang realitas sosial dengan apa yang disajikan dalam televisi (Rakhmat, 2011:247). Tayangan berbau kekerasan emosional terhadap wanita ini mampu memberikan dampak secara psikologis bagi penonton wanita salah satunya perasaan cemas. Hal ini sesuai dengan pendapat dari Dominick (Ardianto dan Erdinaya, 2005:58) bahwa media massa memiliki dampak pada pengetahuan, persepsi, dan sikap. Sikap sendiri terdiri dari kognitif, afektif, dan konatif, sedangkan kecemasan termasuk ke dalam sikap afektif.

Dari data yang dihimpun BPS Kota Serang tahun 2019 jumlah wanita yang menjadi ibu rumah tangga di Kota Serang 90.440 jiwa. Ibu rumah tangga yang dimaksud adalah penduduk berumur 15 tahun keatas yang sudah menikah dan bukan angkatan kerja dalam hal ini hanya mengurus rumah tangga atau housekeeping

Setelah dilakukan pra riset dengan menyebar kuesioner pertanyaan pada 50 responden ibu rumah tangga dari berbagai kalangan, diperoleh hasil bahwa sebanyak $66 \%$ ibu rumah tangga di Kota Serang mengalami kecemasan setelah menonton tayangan Suara Hati Istri, mereka adalah responden yang sering menonton tayangan drama Suara Hati Istri setiap hari selama 4 jam atau dua episode berturut-turut sehingga mereka terpapar oleh tayangan Suara Hati Istri di Indosiar. Kecemasan yang dimaksud yaitu keadaan seorang ibu rumah tangga yang khawatir dan takut akan mengalami tindakan jahat dari suaminya atau berpikir suaminya akan selingkuh setelah menonton tayangan tersebut. Setelah melakukan wawancara secara langsung, perilaku kecemasan yang timbul biasanya adalah sikap posesif kepada suami, menjadi rajin memasak untuk suami, dan sering mengecek ponsel milik suami.

Berdasarkan latar belakang yang telah dipaparkan, hal yang ingin diteliti oleh peneliti adalah Pengaruh Terpaan Tayangan Suara Hati Istri di Indosiar Terhadap Tingkat Kecemasan Penonton Wanita di Kalangan Ibu Rumah Tangga di Kota Serang.

\section{B. KERANGKA TEORI}

\section{Teori Kultivasi}

Teori kultivasi (cultivation theory) pertama kali dikenalkan oleh Profesor George Gerbner ketika ia menjadi Dekan Annenberg School of Communication di Universitas Pennsylvania Amerika Serikat. Menurut teori kultivasi, televisi menjadi 
media atau alat utama di mana para penonton televisi belajar tentang masyarakat dan kultur di lingkungannya. Persepsi apa yang terbangun di benak penonton tentang masyarakat dan budaya sangat ditentukan oleh televisi. Ini artinya, melalui kontak penonton dengan televisi, ia belajar tentang dunia, orang-orangnya, nilai-nilainya serta adat kebiasaannya. (Nurudin, 2015:167).

Menurut Gerbner, sebagian besar yang kita ketahui, atau apa yang kita pikir kita tahu, tidak kita alami sendiri. Kita mengetahuinya karena adanya berbagai cerita yang kita lihat dan dengar melalui media. Dengan kata lain, kita memahami realitas melalui perantaraan media massa sehingga realitas yang kita terima adalah realitas yang diperantarai (Morissan, 2010:253).

Para pecandu berat televisi (heavy viewers) akan menganggap bahwa apa yang terjadi di televisi adalah dunia senyatanya. Misalnya tentang perilaku kekerasan yang terjadi di masyarakat. Para pecandu berat televisi akan mengatakan bahwa sebab utama munculnya kekerasan adalah masalah sosial. Padahal, ada kemungkinan sebab utamanya adalah faktor cultural shock dari tradisional ke modern. Termasuk misalnya pecandu berat televisi mengatakan bahwa kemungkinan seseorang menjadi korban kejahatan adalah 1 berbanding 10, padahal dalam kenyataan angkanya adalah 1 berbanding 50. Dengan kata lain, penilaian, persepsi, opini penonton televisi digiring sedemikian rupa agar sesuai dengan apa yang mereka lihat di televisi. Bagi pecandu berat televisi, apa yang terjadi pada televisi itulah yang terjadi pada dunia sesungguhnya. (Nurudin, 2015: 168).

\section{Terpaan Tayangan Televisi}

Menurut Kriyantono (2008:209) media exposure atau terpaan media lebih dari sekedar mengakses media. Exposure tidak hanya menyangkut apakah seseorang secara fisik cukup dekat dengan kehadiran media massa, akan tetapi apakah seseorang itu benar-benar terbuka terhadap pesan-pesan media massa tersebut. Exposure merupakan kegiatan mendengar, melihat, dan membaca pesanpesan media massa ataupun mempunyai pengalaman dan perhatian terhadap pesan tersebut yang terjadi pada inidividu atau kelompok.

Nielsen Media Research 2008 dalam Media Impact Pengantar Media Massa menyatakan bahwa pada tahun 2008 ratarata waktu yang dihabiskan orang untuk menonton televisi yaitu sekitar 8 jam 18 menit (Biagi, 2010:201).

Dalam penelitian ini, media televisi merupakan media yang menarik untuk dikonsumsi, baik dari segi isi pesan maupun karakteristik $\neg$ nya yang mudah dicerna. Oleh karena itu untuk mengukur terpaan sebuah tayangan televisi, maka indikator yang digunakan adalah frekuensi dan durasi. Frekuensi dalam hal ini yaitu mengumpulkan data khalayak yang menggunakan media mengenai berapa kali sehari seseorang menggunakan media dalam satu minggu untuk meneliti program harian (Elvinaro et al., 2004). Durasi dalam hal ini yaitu menghitung berapa lama khalayak bergabung dengan suatu media (berapa jam sehari); atau berapa lama (menit) khalayak mengikuti suatu program (Elvinaro et al., 2004).

\section{Kecemasan}

Pada dasarnya kecemasan adalah perasaan yang normal dan pernah dialami oleh setiap manusia. Menurut Kaplan, Sadock, dan Greb (Fauziah dan Widuri, 2005:103) kecemasan adalah respon terhadap situasi tertentu yang mengancam, dan merupakan hal yang normal terjadi menyertai perkembangan, perubahan, pengalaman baru, atau yang belum pernah dilakukan, serta dalam menemukan identitas diri dan arti hidup.

Lubis (2009:14) menyatakan bahwa kecemasan adalah tanggapan dari sebuah 
ancaman nyata ataupun khayal. Individu mengalami kecemasan karena adanya ketidakpastian di masa mendatang.

Shah (dalam Ghufron dan Rini Risnawita, 2014:144) membagi kecemasan menjadi tiga aspek, yaitu:

1. Aspek fisik; seperti pusing, sakit kepala, tangan mengeluarkan keringat, menimbulkan rasa mual pada perut, mulut kering, grogi, dan lain-lain.

2. Aspek emosional; seperti timbulnya rasa panik dan rasa takut.

3. Aspek mental atau kognitif; seperti timbulnya gangguan terhadap perhatian dan memori, rasa khawatir, ketidakteraturan dalam berpikir, dan bingung.

Kecemasan yang akan diukur dalam penelitian ini diantaranya berdasarkan aspek fisik, aspek emosional, dan aspek mental. Aspek fisik sendiri meliputi segala macam gangguan fisik akibat terpaan tayangan. Aspek emosional lebih merujuk pada perasaan dan emosi dari penonton atau khalayak. Aspek mental menyangkut ingatan atau memori khalayak.

\section{Audience (Khalayak)}

Khalayak biasa disebut dengan istilah penerima, sasaran, pembaca, pendengar, pemirsa, audience, decoder atau komunikan. Khalayak adalah salah satu aktor dari proses komunikasi. Karena itu unsur khalayak tidak boleh diabaikan, sebab berhasil tidaknya suatu proses komunikasi sangat ditentukan oleh khalayak (Cangara, 2010:157).

Pandangan audience pada suatu program televisi sama seperti perilaku audience yaitu pengetahuan mengenai pola tingkah laku audience, ketika mereka sedang menonton televisi (Morissa, 2008:191).

Menurut Morissan (2008:195-196) perilaku audience yang perlu dicermati adalah adanya kecenderungan audience untuk memilih salah satu stasiun televisi favoritnya dan tetap berada di sana untuk beberapa saat.

\section{Ibu Rumah Tangga}

Ibu rumah tangga adalah wanita yang telah menikah dan tidak bekerja, menghabiskan sebagian waktunya untuk mengurus rumah tangga dan mau tidak mau setiap hari akan menjumpai suasana yang sama serta tugas-tugas rutin (Fadilah et al., 2018). Ibu rumah tangga sebagai wanita yang telah menikah dan menjalankan tanggung jawab mengurus kebutuhan-kebutuhan di rumah.

Menurut Badan Pusat Statistik Kota Serang, ibu rumah tangga adalah perempuan berusia 15 tahun ke atas, bukan bagian dari angkatan kerja, dan mengurus rumah tangga. Sejalan dengan hal tersebut, maka peneliti membuat batasan ibu rumah tangga pada penelitian ini adalah seorang wanita yang sudah menikah, memiliki peran sebagai istri, ibu, dan pekerja rumah tangga.

\section{Hipotesis Penelitian}

Hipotesis pada penelitian adalah:

H1 : Diduga terdapat pengaruh terpaan tayangan Suara Hati Istri di Indosiar Terhadap Kecemasan Penonton

\section{METODOLOGI PENELITIAN}

Sebuah penelitian terikat pada paradigma yang dipilih. Paradigma akan menempatkan seorang peneliti di posisi mana dia memilih sudut pandang sebuah fenomena penelitian. Paradigma berkaitan dengan cara pandang, cara berpikir, hingga cara melakukan sesuatu sehubungan dengan pemilihan paradigma itu sendiri. Paradigma pada penelitian ini adalah menggunakan paradigma positivisme yaitu paradigma yang berupaya untuk menjelaskan dan meramal pola-pola kebenaran dengan mencari hubungan timbal balik atau kausalitas secara pasti.

Penelitian ini menggunakan pendekatan penelitian kuantitatif. Dalam 
penelitian kuantitatif data set dikumpulkan, diolah, dan dianalisis untuk dicari hubungan antar variabel yang diteliti. Variabel yang digunakan dalam penelitian ini ada dua yaitu variabel $\mathrm{X}$ dan variabel Y. Metode yang digunakan dalam penelitian ini adalah metode eksplanasi, karena dalam penelitian ini menggunakan dua variabel. Model eksplanasi adalah suatu metode penelitian yang menggambarkan dua variabel yang diteliti, yaitu variabel bebas dan variabel terikat yang kemudian menjelaskan hubungan atau pengaruh kedua variabel tersebut.

Teknik pengumpulan data menggunakan hasil angket dan observasi. Angket ini akan disebar kepada Ibu Rumah Tangga di Kota Serang. Hasil yang diperoleh melalui angket ini kemudian akan dikumpulkan oleh peneliti dan dianalisis untuk kemudian diambil kesimpulan. Pengukuran variabel dalam angket dilakukan dengan menggunakan skala ordinal (Ghozali, 2006) dengan menggunakan skala likert. Observasi yang dilakukan dalam penelitian ini yaitu mengamati perilaku Ibu Rumah Tangga yang sering menonton tayangan Suara Hati Istri paling tidak di sekitar lingkungan peneliti.

Populasi yang akan diteliti dalam penelitian ini adalah Ibu Rumah Tangga di Kota Serang sebagai responden dengan alasan karena tayangan Suara Hati Istri menceritakan mengenai problematika rumah tangga dan banyak ditonton oleh ibu-ibu rumah tangga. Menurut Badan Pusat Statistik Kota Serang, populasi Ibu Rumah Tangga di Kota Serang tahun 2019 yaitu 90.440 jiwa.

Teknik sampling dalam penelitian ini adalah Teknik Probability Sampling yaitu teknik pengambilan sampel yang memberikan peluang yang sama bagi setiap unsur (anggota) populasi untuk dipilih menjadi anggota sampel. Berdasarkan populasi yang ada maka untuk menghitung jumlah sampel dalam penelitian ini menggunakan rumus Yamane dengan presisi 5\% dengan tingkat kepercayaan 95\%.

$$
\mathrm{n}=\mathrm{N} / \mathrm{Nd} 2+1
$$

Jadi, sampel yang akan diteliti dalam penelitian ini berjumlah 398 responden Ibu Rumah Tangga di Kota Serang.

Analisis linier sederhana diguna-kan untuk mengetahui ada tidaknya kelinieran pengaruh variabel indepen-den terhadap variabel dependen.

$$
\mathrm{Y}=\mathrm{a}+\mathrm{bX}+\mathrm{e}
$$

Koefisien determinasi digunakan pada penelitian untuk mengetahui seberapa besar pengaruh variabel $\mathrm{X}$ yaitu pengaruh terpaan tayangan terhadap variabel $\mathrm{Y}$ yang merujuk pada tingkat kecemasan.

$$
\mathrm{kd}=\mathrm{r} 2 \times 100 \%
$$

Data batas koefisien determinan $0<$ $\mathrm{kd}<1$, dimana kd: 0 berarti pengaruh variabel X terhadap variabel Y lemah. kd: 1 berarti pengaruh variabel $\mathrm{X}$ terhadap variabel Y kuat.

Pengujian hipotesis digunakan untuk membuktikan apakah benar terdapat hubungan antara tayangan drama keluarga Suara Hati Istri dengan tingkat kecemasan Ibu Rumah Tangga yaitu dengan menggunakan uji t sehingga dapat ditemukan apakah hipotesis yang diajukan dapat diterima atau ditolak. Apabila nilai thitung > ttabel, maka hipotesis nol (H0) ditolak dan hipotesis penelitian $(\mathrm{Ha})$ diterima. Apabila thitung < ttabel, maka hipotesis nol (HO) diterima dan hipotesis penelitian (Ha) ditolak 


\section{HASIL DAN PEMBAHASAN}

\section{Gambaran Umum Tayangan Suara Hati Istri di Indosiar}

Suara Hati Istri merupakan program acara televisi yang tayang di stasiun televisi swasta Indosiar dan masuk dalam kategori drama FTV Keluarga. Menurut laman resmi Indosiar, Suara Hati Istri merupakan kisah drama tentang problematika rumah tangga dari sudut pandang seorang wanita yang terinspirasi dari curahan hati para istri yang terzalimi. Tayangan ini mempertontonkan adegan seorang istri yang tersakiti karena ulah suaminya sendiri. Pemeran tokoh istri selalu digambarkan protagonis sementara pemeran tokoh suami antagonis.

Drama FTV Keluarga Suara Hati Istri ini bukan seperti sinetron kebanyakan namun tayangan Suara Hati Istri merupakan judul besar dari kumpulan FTV dengan judul-judul yang lebih spesifik lagi. Tidak seperti kisah sinetron yang bersambung, melainkan cerita di FTV Suara Hati Istri selesai dalam durasi dua jam. Pada episode selanjutnya akan menyajikan kisah yang berbeda lagi.

Suara Hati Istri tayang setiap hari sebanyak dua episode. Episode pertama dimulai pukul $16.30-18.30$ WIB. Setelah itu dilanjut dengan episode keduanya yang berbeda judul pada pukul 18.30 - 20.30 WIB. Dengan begitu, dalam satu kali tayang, Suara Hati Istri membutuhkan waktu 120 menit sudah termasuk iklan.

Tayangan yang terkenal dengan lagu Rossa berjudul Hati Yang Kau Sakiti ini digagas oleh rumah produksi Mega Kreasi Film. Rilis pada tanggal 17 Oktober 2019 lalu dengan judul pertamanya Satu Kesalahan Kubayar Seumur Hidup dan Air Mataku Tak Sebanding Dengan Kebahagiaan Anakku. Judul tiap episode yang disajikan oleh tayangan Suara Hati Istri selalu menggugah emosi penontonnya dan terlihat provokatif, seperti Baju Pengantin Maduku Terbuat Dari Air Mataku, Istri Pengganti, Istri Taruhan, bahkan ada judul terbaru yaitu Covid Membuat Rumah Tanggaku di Ujung Tanduk.
Dari ratusan judul yang sudah tayang, jalan cerita pada FTV Suara Hati Istri memang monoton. Plot cerita memang akan berakhir pada istri yang tersakiti akibat perilaku suaminya. Mayoritas kisah dimulai dengan menampilkan sepasang suami-istri kelas bawah. Mereka berdua saling mencintai dan saling membantu untuk kehidupan yang lebih baik. Setelah kehidupan mereka tercukupi, sang suami tergoda oleh wanita lain dan selingkuh kemudian menceraikan istrinya dan menikah bersama selingkuhannya. Tak lama kemudian sang suami bersama selingkuhannya jatuh miskin sementara istri yang sudah diceraikan perlahan hidup dengan bahagia dan sukses.

Kisah yang cepat menampilkan karma kepada suami yang jahat dan selingkuhannya biasanya adalah kisah yang disukai oleh kebanyakan ibu-ibu.

Meskipun selalu mempertontonkan adegan yang menyedihkan bagi seorang istri, tayangan Suara Hati Istri tentu memiliki pesan dan hikmah yang dapat dijadikan pelajaran bagi setiap orang yang menjalani kehidupan rumah tangga diantaranya janji pernikahan harus dipegang teguh, setiap manusia tidak bisa mengubah sifat orang lain meskipun adalah pasangannya sendiri, seorang istri selalu dianugerahi naluri yang kuat, dalam pernikahan selalu ada saja ujian, serta jangan pernah menyakiti pasangan.

\section{Karakteristik Wilayah Tempat Tinggal Responden}

Penelitian ini memiliki lokus atau tempat penelitian di Kota Serang yang memiliki enam Kecamatan diantaranya Cipocok Jaya, Curug, Kasemen, Serang, Taktakan, dan Walantaka. Penyebaran kuesioner lebih banyak dilakukan pada Kecamatan Cipocok Jaya yaitu sebanyak 68 responden atau $17,1 \%$ dan sisanya memiliki frekuensi yang sama yaitu sebanyak 66 responden atau 16,6\% (Tabel 1). 
Tabel 1

Tempat Tinggal Responden

\begin{tabular}{|l|c|c|}
\hline Kecamatan & Frekuensi & Persentase \\
\hline Cipocok Jaya & 68 & $17,1 \%$ \\
\hline Curug & 66 & $16,6 \%$ \\
\hline Kasemen & 66 & $16,6 \%$ \\
\hline Serang & 66 & $16,6 \%$ \\
\hline Taktakan & 66 & $16,6 \%$ \\
\hline Walantaka & 66 & $16,6 \%$ \\
\hline TOTAL & 398 & $100 \%$ \\
\hline
\end{tabular}

\section{Hasil Uji Normalitas}

Penentuan uji normalitas data menggunakan SPSS 20 yang dilakukan dengan teknik one sample kolmogorovsmirnov test. Hasil tabel uji normalitas data menunjukkan bahwa nilai Asymp.Sig. (2-tailed) pada kolom Unstandardized Residual adalah 0,501. Dengan demikian bahwa data penelitian terdistribusi normal dengan nilai signifikansi 0,501>0,05 (Tabel 2).

Tabel 2

Hasil Uji Normalitas

\begin{tabular}{|l|r|}
\hline & $\begin{array}{r}\text { Unstandar } \\
\text { dized } \\
\text { Residual }\end{array}$ \\
\hline $\mathrm{N} \quad$ Normal Parametersa,b & $0 \mathrm{E}-7$ \\
$\quad$ Mean & 4,230432 \\
Std. Deviation & 19 \\
\hline Most Extreme Differences &, 041 \\
Absolute &, 030 \\
Positive &,- 041 \\
Negative &, 827 \\
Kolmogorov-Smirnov Z &, 501 \\
Asymp. Sig. (2-tailed) &
\end{tabular}

\section{Uji Validitas dan Uji Reliabilitas}

Hasil Uji Validitas (X) Terpaan Tayangan Suara Hati Istri di Indosiar, diketahui bahwa seluruh item pernyataan yang digunakan dalam penelitian ini adalah valid yang ditunjukan dengan nilai dari masing-masing items pernyataan memiliki nilai pearson correlation positif lebih besar dari pada rtabel yang sebesar 0.098 (Tabel 3).

Hasil Uji Validitas (Y) Kecemasan Penonton Wanita pada Kalangan Ibu Rumah Tangga menunjukkan bahwa nilai rhitung pada variabel kecemasan penonton wanita pada kalangan Ibu Rumah Tangga memiliki rentang nilai 0.646-0.401 (Tabel 4).

Tabel 3

Hasil Uji Validitas (X) Terpaan Tayangan Suara Hati Istri di Indosiar

\begin{tabular}{|c|c|c|c|}
\hline No. & R hitung & R tabel & Ket. \\
\hline 1 & 0.690 & 0.098 & Valid \\
\hline 2 & 0.659 & 0.098 & Valid \\
\hline 3 & 0.801 & 0.098 & Valid \\
\hline 4 & 0.797 & 0.098 & Valid \\
\hline 5 & 0.774 & 0.098 & Valid \\
\hline
\end{tabular}

Tabel 4

Hasil Uji Validitas (Y) Kecemasan Penonton Wanita pada Kalangan Ibu Rumah Tangga

\begin{tabular}{|c|c|c|c|}
\hline No. & R hitung & R tabel 5\% & Ket. \\
\hline 1 & 0.401 & 0.098 & Valid \\
\hline 2 & 0.469 & 0.098 & Valid \\
\hline 3 & 0.513 & 0.098 & Valid \\
\hline 4 & 0.454 & 0.098 & Valid \\
\hline 5 & 0.646 & 0.098 & Valid \\
\hline 6 & 0.526 & 0.098 & Valid \\
\hline 7 & 0.598 & 0.098 & Valid \\
\hline 8 & 0.630 & 0.098 & Valid \\
\hline 9 & 0.586 & 0.098 & Valid \\
\hline
\end{tabular}

Nilai cronbach's terpaan tayang-an Suara Hati Istri di Indosiar (0.799>0.6) dan memiliki tingkat reliabel. Kecemasan penon $\neg$ ton wani $\neg$ ta pada kalangan Ibu Rumah Tangga (0.691>0.6) memiliki 
tingkat reliabel. Kedua variabel dalam penelitian ini dapat dikatakan memiliki tingkat reliabilitas yang reliabel karena nilai cronbach's alpha $>0.6$ (Tabel 5)..

Tabel 5

Hasil Reliabilitas Data

\begin{tabular}{|c|c|c|}
\hline \multicolumn{3}{|c|}{ RELIABILITY STATISTIC } \\
\hline VARIABEL & CRONBACH'S & N Of \\
\hline & ALPHA & Items \\
\hline $\mathrm{X}$ & 0.799 & 5 \\
\hline $\mathrm{Y}$ & 0.691 & 9 \\
\hline
\end{tabular}

\section{Analisis Regresi}

Model regresi dapat diinterpretasikan konstanta sebesar 17,205 yang mengandung arti bahwa nilai konsisten variabel partisipasi adalah sebesar 17,205. Koefisien regresi $X$ sebesar 0,576 menyatakan bahwa setiap penambahan 1\% nilai Trust, maka nilai Partisipasi bertambah sebesar 0,576 (Tabel 6). Koefisien regresi tersebut bernilai positif, sehingga dapat dikatakan bahwa arah pengaruh variabel $\mathrm{X}$ terhadap variabel $\mathrm{Y}$ adalah positif.

Tabel 6

Hasil Uji Analisis Regresi Linier Sederhana

\begin{tabular}{|c|c|c|c|c|c|}
\hline \multirow[t]{2}{*}{ Model } & \multicolumn{2}{|c|}{$\begin{array}{c}\text { Unstandardized } \\
\text { Coefficients }\end{array}$} & \multirow{2}{*}{$\begin{array}{c}\text { Standardize } \\
\text { Coefficients } \\
\text { Beta }\end{array}$} & \multirow[t]{2}{*}{$t$} & \multirow[t]{2}{*}{ Sig. } \\
\hline & B & Std. Error & & & \\
\hline (Constant) & t) 17,205 & $5 \quad 1,428$ & & 12,048 & ,000 \\
\hline $\begin{array}{l}1 \text { Terpaan } \\
\text { SHI }\end{array}$ & ,576 & ,077 & 352 & 7,476 & ,000 \\
\hline
\end{tabular}
sebesar 0,527 (Tabel 7) yang menunjukkan nilai $\mathrm{R}$ Square adalah pengaruh terpaan tayangan Suara Hati Istri di Indosiar 52,7\% adalah kontribusi dari kecemasan penonton wanita pada kalangan Ibu Rumah Tangga di Kota Serang, sementara 47,3\% lainnya diterangkan oleh variabel lain yang tidak diteliti dalam penelitian ini.

Tabel 7

Hasil Koefisien Determinasi

\begin{tabular}{ccccc}
\hline Model & $\boldsymbol{R}$ & \multicolumn{2}{c}{$\boldsymbol{R}$} & \multicolumn{2}{c}{ Adjusted Std. Error } \\
& & & & $\begin{array}{c}\text { Estimate } \\
\text { Estime }\end{array}$ \\
\hline 1 &, $726^{\mathrm{a}}$ &, 527 &, 524 & 1,59298 \\
\hline
\end{tabular}

Hasil perhitungan dengan menggunakan bantuan SPSS 20 diperoleh thitung untuk variabel independen tayangan Suara Hati Istri di Indosiar sebesar 7,476 dengan nilai signifikan sebesar 0,000 (Tabel 6). Hasil ini mempunyai arti ada pengaruh positif dari terpaan tayangan Suara Hati Istri di Indosiar terhadap Kecemasan Penonton Wanita pada Kalangan Ibu Rumah Tangga di Kota Serang karena nilai signifikansinya tidak melebihi taraf signifikans yaitu $\mathrm{a}=$ $5 \%=0,05$. Nilai thitung $=7,476$ lebih besar dari ttabel 0,098 maka Ho ditolak dan Ha diterima.

Berarti dengan begitu dapat diketahui bahwa terdapat pengaruh yang signifikan terpaan tayangan Suara Hati Istri di Indosiar terhadap Kecemasan Penonton Wanita pada Kalangan Ibu Rumah Tangga di Kota Serang.

\section{Pembahasan}

Televisi sebagai media audio-visual yang masih eksis di kalangan masyarakat memiliki salah satu fungsi utama yaitu hiburan. Sebagai media hiburan, televisi menayangkan ber-agam program agar dilirik pemirsanya salah satunya adalah program drama. Tayangan Suara Hati Istri masuk ke dalam program drama keluarga. Salah satu segmentasi dari tayangan Suara Hati Istri sendiri adalah Ibu Rumah Tangga dalam hal ini Ibu Rumah Tangga dikategorikan ke dalam wanita yang memiliki suami dan tidak bekerja. Ibu Rumah Tangga dianggap memiliki waktu luang lebih banyak di rumah untuk mengakses televisi.

Tayangan Suara Hati Istri di Indosiar ini selalu mempertontonkan adegan seorang istri yang tersakiti karena ulah suaminya sendiri. Pemeran tokoh istri selalu digambar-kan protagonis sementara pemeran tokoh suami antagonis.

Tayangan Suara Hati Istri di Indosiar memiliki pengaruh terhadap tingkat kecemasan penonton wanita pada 
kalangan Ibu Rumah Tangga di Kota Serang. Sesuai dengan teori kultivasi yang menjadi landasan dalam penelitian ini bahwa Ibu Rumah Tangga di Kota Serang dikatakan mengalami kecemasan setelah menon-ton tayangan Suara Hati Istri di Indosiar dimana pecandu berat televisi dalam hal ini Ibu Rumah Tangga yang menonton tayangan Suara Hati Istri dengan frekuensi dan durasi sering akan merasa bahwa apa yang terjadi pada televisi, itulah yang terjadi di dunia sesungguhnya.

Penonton kelas berat sendiri menurut Gerbner adalah mereka yang menonton televisi minimal empat jam dalam sehari. Tayangan Suara Hati Istri di Indosiar sendiri setiap harinya tayang dua episode dengan durasi per-episodenya yaitu dua jam. Artinya, Ibu Rumah Tangga yang selalu menonton tayangan Suara Hati Istri selama dua episode berturut-turut atau empat jam termasuk ke dalam kategori penonton kelas berat. Dalam penelitian ini terdapat $46 \%$ responden ibu rumah tangga yang memberikan pernyataan setuju bahwa mereka menonton tayangan Suara Hati Istri di Indosiar selama empat jam berturut-turut dan $43 \%$ ibu rumah tangga yang memberikan pernyataan setuju bahwa mereka menonton tayangan Suara Hati Istri di Indosiar selama dua episode berturut-turut. Artinya, mereka adalah kelompok penonton kelas berat. Sehingga dapat disimpulkan dalam penelitian ini teori kultivasi terbukti benar.

Proses kultivasi yang terjadi pada Ibu Rumah Tangga yaitu proses mainstreaming dimana setelah menonton tayangan Suara Hati Istri di Indosiar, ibu rumah tangga akan memandang kenyataan dengan dominasi dari referensi tayangan Suara Hati Istri. Sesuai dengan yang dikatakan Nurudin pada bab sebelumnya bahwa mereka dalam hal ini ibu rumah tangga yang menjadi subjek penelitian akan menganggap bahwa lingkungan di sekitarnya sama seperti yang tergambar dalam televisi dalam hal ini tayangan Suara Hati Istri. Akibatnya, ibu rumah tangga mengalami kecemasan. Mayoritas ibu rumah tangga merasa setuju bahwa mereka takut diselingkuhi suami setelah menonton tayangan tersebut, merasa panik sendiri, serta pada komponen aspek mental ibu rumah tangga mayoritas setuju bahwa mereka menjadi lebih perhatian pada suami, sering mengingat-ingat peristiwa kecil dengan suami, bahkan khawatir akan perubahan kecil pada diri suaminya.

Proses resonance tidak dialami oleh Ibu Rumah Tangga yang menonton tayangan Suara Hati Istri, sebab tidak semua Ibu Rumah Tangga mengalami apa yang ada pada tayangan Suara Hati Istri. Mayoritas responden tidak benar-benar meng-alami suami mereka berseling $\neg$ kuh, melakukan tindakan kekerasan, atau menunjukkan perubahan sikap dan perilaku yang signifikan.

\section{E. PENUTUP/CONCLUSION}

Berdasarkan hasil uji hipotesis antara variabel X (Terpaan Tayangan Suara Hati Istri di Indosiar) terhadap variabel $\mathrm{Y}$ (Tingkat Kecemasan Penonton Wanita pada Kalangan Ibu Rumah Tangga di Kota Serang) diperoleh nilai bahwa thitung 7,476 lebih besar dari ttabel 0,098 dengan begitu dapat diketahui bahwa terdapat pengaruh yang signifikan antara terpaan tayangan Suara Hati Istri di Indosiar terhadap tingkat kecemasan penonton wanita pada kalangan Ibu Rumah Tangga di Kota Serang. Sementara hasil koefisien determinasi, pengaruh terpaan tayangan Suara Hati Istri di Indosiar terhadap tingkat kecemasan penonton wanita pada kalangan Ibu Rumah Tangga di Kota Serang yaitu sebesar 52,7\% dan sisanya 47,3\% dipengaruhi oleh faktor lain yang tidak diteliti dalam penelitian ini. 


\section{DAFTAR PUSTAKA}

Abdullah, A., \& Puspitasari, L. (2018). Media televisi di era internet. ProTVF, 2(1), 101-110. https://doi.org/https://doi.org/10.2 4198/ptvf.v2i1.19880

Biagi, S. (2014). Media/Impact: An Introduction to Mass Media. Cengage $\mathrm{L} \quad \mathrm{e} \quad \mathrm{a} \quad \mathrm{r} \quad \mathrm{n} \quad \mathrm{i} \quad \mathrm{n} \quad \mathrm{g}$. https://books.google.co.id/books?id $=$ WObAAgAAQBAJ

Elvinaro, A., Lukiati, K., \& Karlinah, S. (2004). Komunikasi Massa Suatu Pengantar. Bandung: Simbiosa Rekatama Media.

Erana, G. (2015). Kredibilitas Kader Pusat Informasi dan Konseling (PIK) dalam Menginformasikan Program Penyiapan Kehidupan Berkeluarga bagi Remaja di Kelurahan Dadi Mulya Kota Samarinda. Jurnal Ilmu Komunikasi Fakultas Ilmu Sosial Dan Ilmu Politik, Universitas Mulawarman, 4(2), 224-238. https: / / ejournal.ilkom.fisipunmul.ac.id/site/?p=2561

Etiafani, E., \& Listiara, A. (2015). SelfRegulated Learning dan kecemasan akademik pada siswa SMK. Empati, 4(4), 144-149. https://ejournal3.undip.ac.id/index. php/empati/article/view/13674

Fadilah, N., Sudaryanto, E., \& Norhabiba, F. (2018). Pengaruh Tayangan Modern Moms Trans7 Terhadap Pola Asuh Demokratis pada Ibu Rumah Tangga. Jurnal Representamen, 4(02), 26-32. h t t p : / / j u r n a l. u n t a g sby.ac.id/index.php/representamen/ article/view/1738

Ghozali, I. (2006). Aplikasi analisis multivariate dengan program SPSS. Semarang: Badan Penerbit Universitas Diponegoro.

Ghufron, M. N., \& Risnawita S, R. (2010). Teori-teori psikologi.

Hajar, I. (2018). Youtube sebagai Sarana Komunikasi Dakwah di Kota Makassar (Analisis Sosial Media). Jurnal Al-Khitabah, 4(2), 95-109. h t t p : / / journ a l u i n alauddin.ac.id/index.php/AlKhitabah/article/view/6951

Kuswandi, W. (1996). Komunikasi massa: sebuah analisis isi media televisi. Jakarta: Rineka Cipta.

Morrissan, M. A., Corry, A., Budiyanto, H., \& Olii, H. (2005). Media penyiaran: strategi mengelola radio dan televisi. Jakarta: Ramdina Prakarsa.

Nurudin, N. (2007). Pengantar Komunikasi Massa. Jakarta: RajaGrafindo Persada.

Pangase, I. N., \& Sugandi, G. (2018). Analisis Terpaan Media Terhadap Kecemasan Ibu Rumah Tangga Di Kelurahan Loa Bakung Samarinda (Studi Kasus Kekerasan Seksual Yuyun). EJournal Ilmu Komunikasi, 6(3), 633-647. https: / / ejournal.ilkom.fisipunmul.ac.id/site/?p=3591

Rakhmat, J. (2015). Psikologi komunikasi. Bandung: PT Remaja Rosdakarya.

Siswanti, E., \& Lestari, S. P. (2019). Hubungan Frekuensi Menonton Tayangan Budaya Korea (K-Pop) Dan Pengimitasian Sikap Pada Pelajar Di SMP Eka Sakti Banyumanik Semarang Tahun 2019. Jurnal Egaliter, 3(5), 90-106.

Yuliati, N. (2005). Televisi dan Fenomena Kekerasan Perspektif Teori Kultivasi. Mediator: Jurnal Komunikasi, 6(1), $\begin{array}{llllll}1 & 5 & 9 & - & 1 & 6\end{array}$. https://elearning2.unisba.ac.id/inde x.php/mediator/article/view/1185 